\title{
Britain cheers and jeers at a status quo White Paper
}

London. The establishment is happy; its critics are not. That, in a nutshell, summarizes reaction to the British government's White Paper (policy document) on the organization of science and technology, Realising our Potential, published last week in London.

The lack of radical change has reassured those who feared that William Waldegrave, the Chancellor of the Duchy of Lancaster and as such the cabinet minister responsible for science, would use the report to re-

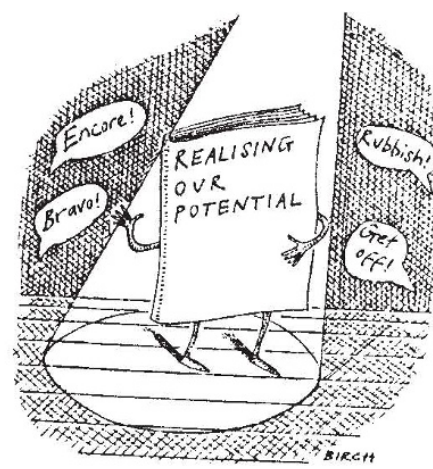

distribute the government's responsibilities for research.

Universities, for example, are pleased with the decision to maintain the dual support system. The research councils are similarly relieved that Waldegrave rejected a suggestion by the Advisory Council on Science and Technology (ACOST) to privatize many of their research institutes and separate the funding of basic and applied research (see Nature 360, 614; 1992).

Ironically, the Medical Research Council, which would have been most affected by this plan and was one of its sharpest critics, emerges as a model for the other research councils since it already has a part-time chairman from industry and a full-time chief executive officer. "I am very pleased with the White Paper", says MRC secretary Dai Rees. "The implementation of ACOST's proposals would have been a loss to the nation."

Tom Blundell, the chairman of the Agricultural and Food Research Council, which will be expanded into a new Biotechnology and Biology Research Council (BBRC), says that he welcomes the shift in emphasis as the 'coming of age' of biology-based industry. Industry itself appears pleased with its new 'partnership' role, heavily influenced by input from Michael Heseltine, the minister responsible for the Department of Trade and Industry (DT1).

This role will be achieved, for example through the presence of prominent industrialists on the new Council of Science and Technology, which will replace ACOST, and their increased role in recommending priorities for the research councils. DTI officials describe the White Paper as a "victory' for Heseltine's approach, while Fiona Steele of the Confederation of British Industry says simply, "we like it".

In contrast, those who had been pushing Waldegrave for more radical changes are frustrated over, for example, the lack of any commitment to significant increases in funding for science, or of any promise to shift spending on military research and development into the civilian sector.

"The absence of either of

\section{Waldegrave gets help}

The British government has replaced a classicist with a science graduate and former business manager to serve as junior minister to William Waldegrave, the cabinet minister responsible for science. Part of his job will be to help implement plans for a reorganization.

In last week's cabinet reshuffle, David Davis, who studied molecular sciences and computer science at the University of Warwick and worked for the sugar company Tate and Lyle before entering Parliament in 1987, replaced Oxford-educated Robert Jackson as Parliamentary Under-secretary at the Office of Public Service and Science. Another casualty of the reshuffle was Edward Leigh, a junior minister in the Department of Trade and Industry (DTI).

Attention in Whitehall is now turning to the crucial post of director-general of research councils. Two potential candidates are Sir Mark Richmond, who will lose his position as chairman of the Science and Engineering Research Council when the council is split in three later this year, and Geoffrey Robinson, chief scientist at the DTI. D.D. these is a great disappointment", says John Mulvey of the department of physics at the University of Oxford, secretary of the Save British Science campaign. Mulvey says that pressure on research councils to emphasize their role in wealth creation and to focus on priorities decided by industry "is a considerable lurch to more state control". ing scientific staff have criticized the White Paper's declared intention to continue the privatization of government-funded research laboratories. "We welcome the White Paper's proposals to be more open about setting priorities for science, but we don't like the dogma about privatization," says Valerie Ellis, assistant general sec-
Trade unions represent-
A global search

Britain's Department of Trade and Industry is to establish an international network of technology counsellors to gather information about new scientific and technical advances that could be of benefit to British industry. The initiative is one of a number of developments announced last week by Michael Heseltine, the minister for the department, to coincide with the publication of the government's White Paper.

"Our role is to help British industry make better use of research," says Edward Leigh, who was until last week a junior minister for trade and industry, and actively engaged in challenging efforts by the Foreign Office to cut back support for science attachés working in British embassies abroad (see Nature 363, 101; 1993). "Since only a small proportion of the world's R\&D is carried out in Britain, it makes sense to find out more about what the rest of the world is doing."

D.D.

retary of the Institution of Professional Managers and Specialists. The union's members include 90,000 scientists and other specialists, many of whose jobs could be threatened.

The opposition Labour Party has been even stronger in its condemnation. Science spokesman Lewis Moonie described the White Paper as a "complete failure" that condemns Britain to "hobbling into the future with an underfunded science base".

Reaction is mixed to the White Paper's proposals for improving the career prospects for scientists. Many have applauded the introduction of a one-year MSc for graduates before embarking on a $\mathrm{PhD}$ - "a welcome move towards US practice", says Sir Martin Rees, professor of astronomy at the University of Cambridge - as well as new measures to encourage universities to provide scientists with more stable careers.

But there has also been criticism of the government's intention to introduce a more careful selection of $\mathrm{PhD}$ candidates, leading to fewer graduates studying for such degrees. While the research councils see this as a better use of scarce resources, David Triesman, president of the Association of University Teachers, says that it "will give the wrong signal to our brightest students".

There is also concern about the impact on research of splitting the Science and Engineering Research Council (SERC) into two bodies: an Engineering and Physical Science Research Council and a Particle Physics and Astronomy Research Council (PPARC). In particular, some fear that the increased exposure of "big science" to political influence could make it more vulnerable to attempts at seeking quick reductions in the science budget.

David Dickson 